\title{
TRAINING IN ADOPTION OF DIGITAL MARKETING TO INCREASE BRANDING AND INTAKE OF LANTERA BANGSA SCHOOL
}

\author{
Rini Kurnia SARI ${ }^{1 *}$, Davy Ronald HERMANUS ${ }^{2}$, Faradila ANJANI ${ }^{3}$, and Vina ROSALIA ${ }^{4}$ \\ ${ }^{1,3,4}$ Management Department, BINUS Online Learning, Bina Nusantara University, Jakarta, Indonesia, \\ ${ }^{2}$ School of Creative Technology Binus Bandung, Bandung, Indonesia \\ *rini@binus.ac.id
}

\begin{abstract}
Lentera Bangsa School is an educational institution that runs community homeschooling \& single homeschooling programs. This community service (PkM) activity run focuses on appropriate technology by creating technological innovations to increase sales. Building digital marketing was chosen as the final result with the aim that Lentera Bangsa School can improve branding or brand recognition and increase competition with other schools through online marketing. Digital marketing is a marketing activity carried out using electronic media and internet networks. Digital marketing is done using a website. The website was built to display the products offered, school profiles, teaching and learning activities and other activities in an attractive and professional manner. The website can be used as a medium to increase intake or the number of students who join online, because this website was built with an interactive concept between prospective students and the school. Besides being interactive, interaction through the website must be more effective and efficient. After the website is built, the next step in introducing the website can be done through social media such as youtube, facebook and instagram. After the website is built, periodic evaluation, improvement and development will be carried out, so that there will be continuous sustainability.
\end{abstract}

Keywords: Innovation, Technology, Digital, Marketing, Website, Intake, Branding

\section{BACKGROUND}

Lentera Bangsa School, which was established in 2011, conducts marketing and branding to prospective students by participating in exhibitions and based on direct visits. But since 2020 coincided with the covid-19 pandemic, offline marketing is not effective.

The covid-19 pandemic has a negative impact on the marketing of Lentera Bangsa School because during this pandemic the government requires the public to carry out large-scale social restrictions (PSBB). With the PSSB, it certainly changes consumer behavior in making face-toface purchases. Before the pandemic, prospective students preferred to come directly to school offline because they could see activities at the school. After a pandemic, consumers prefer buying or registering from home (online).

Lentera Bangsa School as a foster partner of Binus University is currently experiencing problems in marketing activities. This is because Lentera Bangsa School does not do digital marketing. Marketing is not done online due to several things, including a lack of understanding about digital marketing and not having the means or media to do digital marketing.

The problem faced Lentera Bangsa School is that they currently do not have a website so that during this pandemic period they cannot compete with competitors who already have websites. Marketing and sales have been done online through the website. But running short because of a lack of knowledge in running digital marketing. School marketing is only done offline, so sales reach is still very limited. Branding has not been able to attract consumers to make product purchases so that it has not been able to increase sales. The branding that is formed is also not yet known to the wider community because there are still limitations of online marketing. The display of photos and videos related to products is still not attractive, so that the marketing carried out is not optimal.
In the face of the current pandemic, the business world must adapt quickly. Adaptation can be done by innovating. Technological innovation is currently needed, one of which is innovating in marketing activities by using digital marketing. Digital marketing is done using electronic media and the internet. There are advantages in using the internet for marketing purposes, one of which is the use of websites (Ritz, 2019). Website is an interactive technology that facilitates two-way marketing communication in building a brand, increasing customer loyalty, and improving business performance (Bacile, 2014; Chawanuan, 2015).

Digital Marketing has expanded the boundaries of education. In this era, educational institutions around the world are no longer difficult to market themselves to the wider community according to their targets. With this digital marketing, it is hoped that understanding of a branding will be increase. Due to the large dissemination of information, educational institutions have the opportunity to demonstrate the opportunities that students can derive from the services they provide, not only in the country but in the world market (Baltes, 2015).

\section{METHOD}

The method of community service is carried out through discussion, counseling, digital website design training and social media content development. Digital marketing using digital platform tools is considered the most efficient way to reach potential consumers (Kannan, 2017). This service activity is carried out for educators and teachers at Lentera Bangsa School. The smooth running of this service activity is also supported by the participation of Binus University students. Students assist in provide marketing strategy ideas, administrative and documentation activities. 


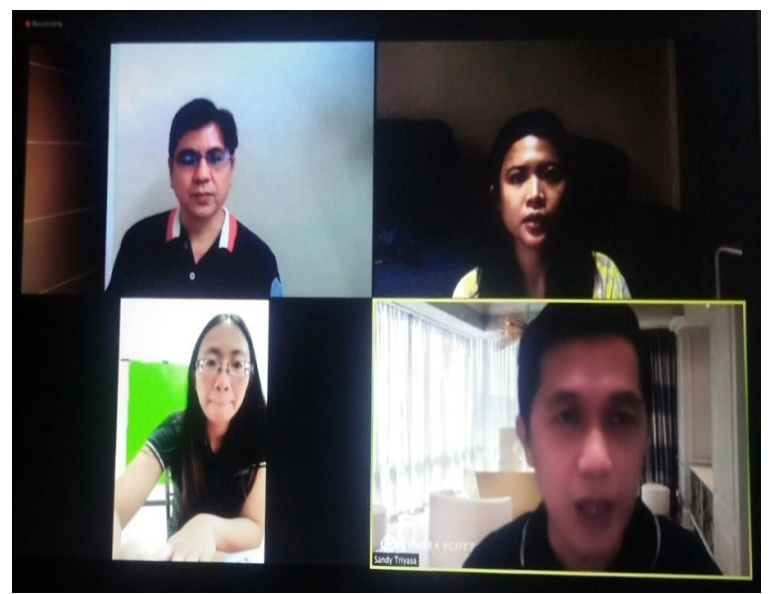

Picture 1. Discussion and counseling Regarding The Problems Faced by Lentera Bangsa School

The implementation method is carried out through discussions with the owners of the Lentera Bangsa School through zoom meetings and whatsapp groups. The first activity is through analysis of the current marketing system and how to provide improvement solutions. We propose community service with an information system development approach by adopting materials related to digital marketing. Of course, before carrying out promotions, all aspects of the product and the readiness of human resources who are ready to become good customer support must be addressed and provide distribution channels to customers and after that maintain those who have already purchased.

The real output can be enjoyed by the owner in the form of a website that can be enjoyed by the general public and can be used as a means of interaction with Lentera Bangsa School efficiently and effectively. Because this activity will produce one of the outputs in the form of an international scale paper, it is hoped that many academic parties can develop it for other activities.

The field of management science is an applied field of science, one of which is studying marketing theory. Marketing theory is a theory that explains the company's strategy to increase sales and business development. If collaborating with information technology science, the results of this collaboration are expected to be able to improve the economy of the partner community through coaching both in marketing and sales to all levels of society in terms of innovation. Innovating can be through marketing development through electronic media or digital marketing.

To build digital marketing in accordance with current needs, website creation and training on the use of the website as community service assistance from Bina Nusantara University to Lentera Bangsa School with a team of trainers who are a combination of multidisciplinary and active students to conduct socialization, design and related analysis

digital marketing, it is hoped that this program will be an activity for the application of appropriate science and technology for Lentera Bangsa School.

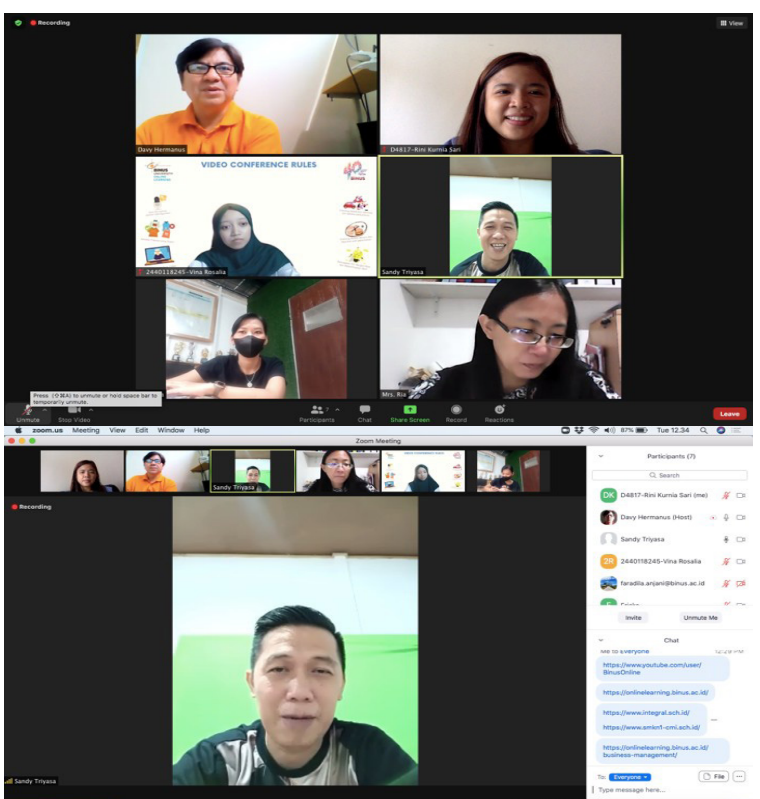

Picture 2. Training Design Website and Social Media Development

Digital marketing has four main aspects found in business platforms, namely website/mobile marketing, search engine optimization, social media, and customer relationship management (Kannan, 2017). Partners will work closely with a team of trainer in training on website design, website management, strategies in using search engine optimization, content design on social media and utilization of customer relations management which is used to improve branding and student intake at Lentera Bangsa School.

Partners are expected to have increased expertise in digital marketing by using facilities such as website, search engine optimization and social media.

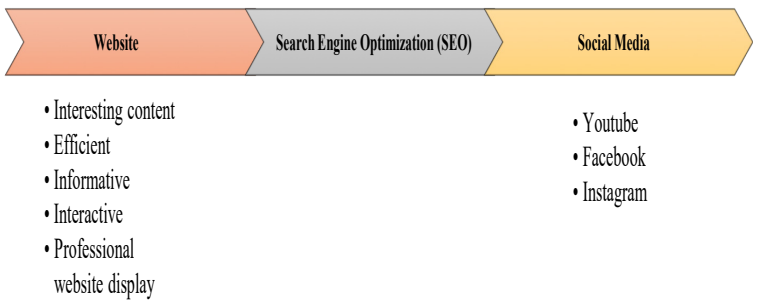

Picture 3. Digital Marketing

Source: Kannan (2017)

Table 1. Training Targets

\begin{tabular}{|c|c|c|c|c|}
\hline No. & Outer Type & Website & SEO & Social Media \\
\hline 1 & Business strategy & $\mathrm{x}$ & $\mathrm{x}$ & $\mathrm{x}$ \\
\hline 2 & $\begin{array}{l}\text { Professional and } \\
\text { attractive UI/UX design } \\
\text { for websites }\end{array}$ & $\mathrm{x}$ & & \\
\hline 3 & $\begin{array}{l}\text { Development of } \\
\text { informative content } \\
\text { about homeschooling }\end{array}$ & & & $\mathrm{x}$ \\
\hline 4 & $\begin{array}{l}\text { Significant increase in } \\
\text { engagement between } \\
\text { schools andnew } \\
\text { customers }\end{array}$ & $\mathrm{x}$ & & $\mathrm{x}$ \\
\hline 5 & $\begin{array}{l}\text { Improved marketing } \\
\text { understanding }\end{array}$ & $\mathrm{x}$ & & $\mathrm{x}$ \\
\hline
\end{tabular}


Website can help to develop a highly targeted business (Ferris, 2007). Based on the discussion between the trainer and the Lentera Bangsa School, it was agreed on several targets or outcomes of the training to be carried out. In table 1 can be seen the results of the training targets to be achieved.

\section{RESULTS AND DISCUSSION}

This community service is carried out by applying a combination of three fields of knowledge, namely management science, information systems science and information engineering science. Management science will be used in determining marketing strategy. Information systems science is used in the development of information systems to support the management of an organization or company. Information engineering science is used in interactive design and UI/UX.

Based on data from hootsuite(weare social): Indonesian digital report 2020, the most social media users in Indonesia are youtube, followed by the most users on facebook and the next three biggest are instagram. Thus, the focus of content development is only on the three social media.

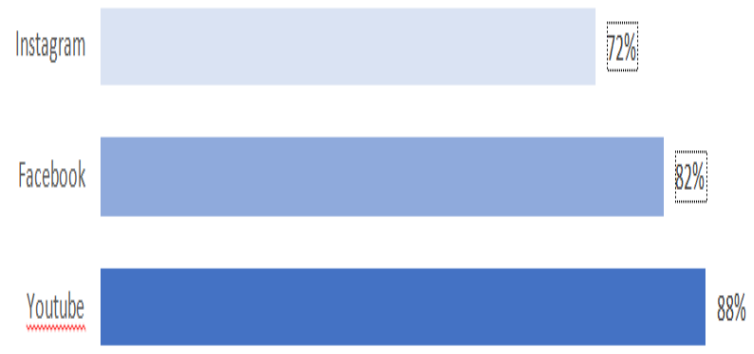

Picture 4. Most-Used Social Media Platform, 2020

Source: Hootsuite (We Are Social): Indonesian Digital Report 2020

After analyzing the problems faced by Lentera Bangsa School, we as trainers provide solutions based on previous research. Then we matched the theory with the needs of Lentera Bangsa School to get the best solution. After there is a solution, training and development are carried out so that the results of this activity are obtained. Table 2 shows that these community service activities can be applied directly and the technology used is appropriate.

\section{CONCLUSION}

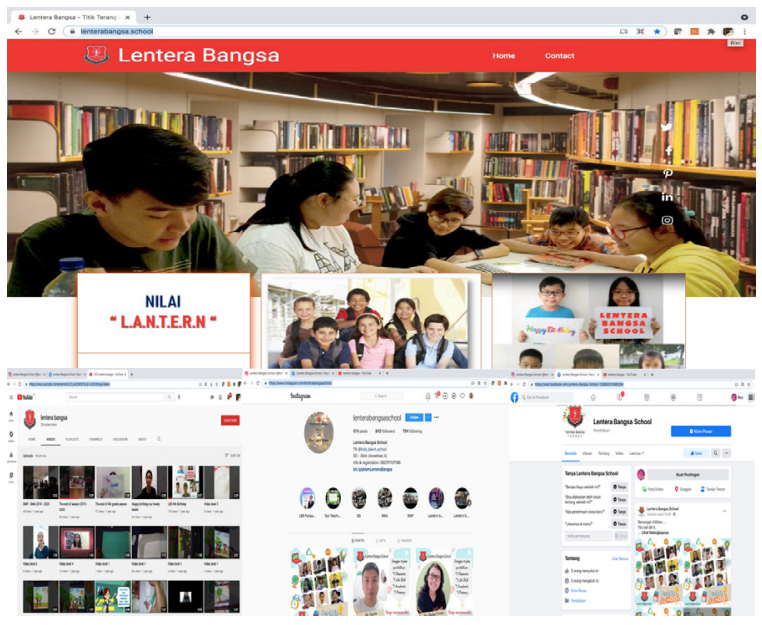

Picture 5. Website, Youtube, Facebook and Instagram Lentera Bangsa School

Community service activities for Lentera Bangsa School went well. Lentera Bangsa School can create a website design with a professional appearance according to the needs of the school and the needs of prospective students. After conducting this training, Lentera Bangsa School also has knowledge in content development on social media. With training related to digital marketing,

Lentera Bangsa School has the ability to improve marketing through electronic media. In order for the digital marketing carried out by Lentera Bangsa School to be carried out in a sustainable manner, the trainers always carry out monitoring and evaluation.

\section{ACKNOWLEDGMENT}

We would like to thank the community development of Bina Nusantara University which has facilitated community service activities. We express our deepest gratitude to Lentera Bangsa School and Binus University students for the good cooperation during the training. This community service can run smoothly thanks to the full support from the leadership of Binus Online Learning.

Table 2. Marketing on website and social media

\begin{tabular}{|c|c|c|}
\hline Problem & Solution & Result \\
\hline Don't have a professional website & $\begin{array}{l}\text { Websites must be interactive, focused and } \\
\text { measurable (Lamberton \& Stephen, 2016) } \\
\text { Website must have a concept that creates an engaging } \\
\text { experience for consumers (Brosnan, 2012) }\end{array}$ & $\begin{array}{l}\text { Design content on the website } \\
\text { (https://lenterabangsa.school) }\end{array}$ \\
\hline Content is not interesting & $\begin{array}{l}\text { The video displayed must have effective information about } \\
\text { homeschooling (Wielki, 2020) Making videos that tell } \\
\text { students' positive experiences with school (Baron, 2014) }\end{array}$ & $\begin{array}{l}\text { Design content on youtube } \\
\text { (https://www.youtube.com/ } \\
\text { channel/UCXJx5D9tSPQvQI- } \\
\text { vDEVdmyg/videos) }\end{array}$ \\
\hline Content is not interesting & $\begin{array}{l}\text { Creating groups, events, profile page, facebook pages } \\
\text { (Farooq, 2012) }\end{array}$ & $\begin{array}{l}\text { Design content on facebook } \\
\text { (https://web. facebook.com/ } \\
\text { Lentera-Bangsa-School- } \\
\text { 103660074985284) }\end{array}$ \\
\hline Content is not interesting & $\begin{array}{l}\text { Published content must involve students, parents and teachers } \\
\text { on the experience school at Lentera Bangsa School and the } \\
\text { experience of using the facilities (Baron, 2014) }\end{array}$ & $\begin{array}{l}\text { Design content on instagram } \\
\text { (https://www.instagram.com/le } \\
\text { nterabangsaschool/) }\end{array}$ \\
\hline
\end{tabular}




\section{REFERENCES}

Afrilia, A. M. (2018). Digital marketing sebagai strategi komunikasi pemasaran "waroenk ora umum" dalam meningkatkan jumlah konsumen. Jurnal Riset Komunikasi, 1(1), 147-157.

Bacile, T.J., Ye, C. and Swilley, C. (2014). From firmcontrolled to consumer-contributed: consumer co- production of personal media marketing communication. Journal of Interactive Marketing. Vol. 28 No. 2, pp. 117-133.

Baron, Elżbieta \& Ciechomski, Wiesaw. (2019). Instagram as a New Promotion and Sales Channel.10.12657/9788379862771-2.

Brosnan, F. (2012). Business intelligence: What works where in B2B digital marketing. Journal of Direct, Data and Digital Marketing Practice , 14 (2), 154 159.

Chawanuan, K., Jung, S. and Watchravesringkan, K. (2015). Building customer equity through trust in social networking sites: a perspective from Thai consumers. Journal of Research in Interactive Marketing. Vol. 9 No. 2, pp. 148-166.

Effing, R., van Hillegersberg, J., \& Huibers, T. (2016). Social Media Indicator and Local Elections in the Netherlands: Towards a Framework for Evaluating the Influence of Twitter, YouTube, and Facebook. Social Media and Local Governments, 281-298. doi:10.1007/978-3-319-17722-9_15

Farooq, Faraz and Jan, Zohaib. (2012). The Impact of Social Networking to Influence Marketing through Product
Reviews. International Journal of Information and Communication Technology Research. Vol. 2 No. 8.

Ferris, M. (2007). Insights on mobile advertising, promotion, and research. Journal of Advertising Research. Journal of Advertising Research, 47 (1), 28-37.

Kannan, P. (2017). Digital marketing: A framework, review and research agenda. International Journal of Research in Marketing, 34 (1), 22-45.

Lamberton, Cait; Stephen, Andrew T. (2016). A Thematic Exploration of Digital, Social Media, and Mobile Marketing: Research Evolution from 2000 to 2015 and an Agenda for Future Inquiry. Journal of Marketing, 80(6), 146-172. doi:10.1509/jm.15.0415

Patrutiu Baltes, L. (2015). Content marketing - the fundamental tool of digital marketing. Bulletin of the Transilvania University of Brasov. Series V: Economic Sciences, 8 (2), 111-118.

Ritz, W., Wolf, M. and McQuitty, S. (2019), "Digital marketing adoption and success for small businesses: The application of the do-it-yourself and technology acceptance models", Journal of Research in Interactive Marketing, Vol. 13 No. 2, pp. 179-203. https://doi.org/10.1108/JRIM-04-2018-0062

Wielki, Janusz. 2020. "Analysis of the Role of Digital Influencers and Their Impact on the Functioning of the Contemporary On-Line Promotional System and Its Sustainable Development" Sustainability 12, no. 17: 7138. https:// oi.org/10.3390/su1217713 